\title{
Analisa Perbandingan Kekuatan Profil Padeye Berdasarkan Desain Standara DNV dan BS-EN Studi Kasus: Cargo Carrying Unit
}

\author{
F. Noviantoro* dan I.Kusumaningtyas \\ Departemen Teknik Mesin dan Industri, Fakultas Teknik, Universitas Gadjah Mada. \\ Jl. Grafika No.2, Kompleks UGM, Yogyakarta 55281, Indonesia, \\ Telp. (0274) 521673 \\ *E-mail: feri.noviantoro@mail.ugm.ac.id
}

\begin{abstract}
Abstrak
Pada industri minyak, gas bumi, fabrikasi, manufaktur dan konstruksi, lifting merupakan salah satu aktivitas penting yang sering dilakukan. Konfigurasi lifting memerlukan analisis komprehensif untuk memastikan struktur lifting tersebut aman untuk dipergunakan. Alat lifting yang paling sering digunakan adalah Cargo Carrying Unit (CCU), sebuah struktur yang di desain dan digunakan berulang kali dalam kegiatan pengangkutan barang. Faktor terpenting dari keamanan desain CCU adalah desain lifting point-nya, atau biasa disebut padeye. Dalam penentuan desain padeye, rujukan standar desain yang paling umum digunakan adalah DNV dan BS-EN. Analisis ini diharapkan dapat menghasilkan perbandingan regangan dan displacement yang terjadi untuk pemodelan desain padeye yang merujuk pada DNV dan BS-EN. Dan juga, untuk membandingkan nilai tegangan pada masing - masing desain terhadap batasan tegangan yield material yang digunakan. Selain itu, nilai persentase tegangan dan momen puntir maksimum pada saat mencapai 100\% dari batasan SMYS-nya juga akan dilakukan tinjauan. Untuk menunjang keakuratan hasil analisis, tinjauan struktur padeye menggunakan analisis FEM (finite element method) pada segmen padeye-nya. Penelitian ini diharapkan bisa menjadi referensi pertimbangan bagi perusahaan untuk mengantisipasi perilaku padeye terhadap beban tarik dan puntir.
\end{abstract}

Kata kunci : lifting, rigging, padeye, structure, Cargo Carrying Unit, FEM.

\begin{abstract}
In In the oil, natural gas, fabrication, manufacturing and construction industries, lifting is one of the most important activities that often carried out. A comprehensive lifting configuration is to ensure the lifting structure is safe to be used. The most model for lifting tool is the Cargo Carrying Unit (CCU), a structure that is used repeatedly in goods transportation activities. The most important factor of the safety of the CCU design is the lifting point design, or so-called padeye. In determining the padeye design, the most commonly used reference design standards are DNV and BS-EN. This analysis is expected to produce a comparison of strain and displacement that occurs for padeye design modeling that refers to DNV and BS-EN. Also, to compare the stress value in each design against the yield stress limit of the material used. In addition, the percentage value of the maximum stress and torque when it reaches $100 \%$ of the SMYS limit will also be reviewed. To support the accuracy of the analysis results, the padeye
\end{abstract}


structure review uses the FEM (finite element method) analysis on its padeye segment. This research is expected to be a reference consideration for companies to anticipate padeye behavior towards tensile and torsional loads.

Keywords : lifting, rigging, padeye, structure, Cargo Carrying Unit, FEM.

\section{PENDAHULUAN}

Industri di bidang minyak dan gas bumi, fabrikasi, manufaktur dan konstruksi, lifting merupakan salah satu tahapan terpenting, sehingga diperlukan perhitungan dan analisis yang memadai untuk memperhatikan apakah struktur lifting tersebut aman atau tidak. Skenario dalam proses lifting berdasarkan konfigurasi perencanaan rigging dibuat untuk menentukan peralatan rigging yang tepat (Gayuh, 2016). Dalam perencanaan lifting dan rigging tersebut, dipertimbangkan beberapa faktor antara lain analisa statis dan dinamis (Gusti, 2013).

Banyak hal perlu diantisipasi yang dapat menyebabkan kegagalan struktur dan peralatan rigging saat kegiatan lifting dilakukan. Beban struktur yang diperhitungkan mempertimbangkan beberapa faktor yang akan terdistribusi melalui titik angkat dan menjadi beban langsung pada padeye-nya.

Cargo Carrying Unit (CCU) adalah sebuah unit struktur yang didesain untuk digunakan secara berulang kali di dalam kegiatan pengangkutan barang dan peralatan dari dan ke anjungan lepas pantai, fasilitas darat ataupun kapal. Terdapat beberapa jenis CCU yang biasa digunakan dalam industri migas, yaitu jenis kontainer, kontainer tangki, skid dan keranjang (basket).

Metode lifting harus memperhatikan banyak faktor seperti kapasitas crane, lifting point, book point, shackle, padeye dan sling. Berdasarkan informasi yang didapat, analisis dinamis pada proses lifting mencakup dari beban yang terjadi dan dasar penentuan beban dari kegiatan lifting adalah berat struktur itu sendiri, center of gravity, berat riging, dan beban yang akan diangkut (Pramita, 2013).

Batas kekuatan desain tersebut diatur dalam kode dan standar yang berlaku. Dalam kode dan standar ditetapkan persyaratan-persyaratan yang dianggap perlu agar desain padeye ini tidak akan mengalami berbagai modus kegagalan. Dengan demikian, setiap tahap lifting, misalnya pemilihan metode lifting, penentuan dimensi dan material, perhitungan beban dan tegangan yang diizinkan, dan lain-lain harus selalu mengacu pada aturan-aturan yang ditetapkan oleh kode dan standar tersebut. Standar yang digunakan dalam analisis lifting ini adalah DNV 2.7-1 Offshore Containers 2013 dan BS EN 12079-1:2006 - Offshore containers and associated lifting sets.

Penelitian ini bertujuan untuk melihat lebih detail analisa perhitungan dimensi optimal padeye dengan merujuk kepada standar DNV dan BS-EN yang ditinjau menggunakan FEM pada segmen padeye-nya.

Analisa ini menggunakan program Abaqus untuk mendapatkan solusi yang efisien tentang perilaku padeye jika mengalami beban tarik dan puntir yang melebihi kapasitas desain. Penelitian ini juga diharapkan menjadi referensi bagi perusahaan untuk mengantisipasi perilaku padeye jika terjadi kesalahan pengoperasian di lapangan. Selain itu, diharapkan analisis ini bisa menjadi sumber literatur rujukan para peneliti selanjutnya untuk dikembangkan lagi desain yang dapat memperbesar persentase ketahanan struktur padeye terhadap beban tarik dan beban puntir. 


\section{METODE PENELITIAN}

Penelitian ini di awali dengan studi literatur untuk konsep desain awal CCU. Pertama dengan memodelkan struktur CCU, pemilihan material, penentuan jenis dan besar beban yang terjadi. Ketiga data input tersebut diolah terlebih dahulu menggunakan program analisis struktur. Output yang didapatkan adalah nilai WLLmin, tegangan tarik dan tegangan puntir yang akan digunakan untuk menentukan kapasitas shackle-nya dan selanjutnya untuk menentukan dimensi padeye-nya. Dimensi padeye yang sudah didapat dari tabel shackle (Crosby, 2003) akan dimodelkan berdasarkan standar DNV 2.7-1 dan BS-EN 12079-1:2006.

\subsection{Desain Padeye}

Berdasarkan rujukan standar (BS-EN 12079-1, 2006) dan (DNV 2.7-1, 2013) berikut adalah tabel komparasi pemodelan padeye-nya.

Tabel 1. Perbandingan Standar BS-EN dan DNV dalam penentuan padeye

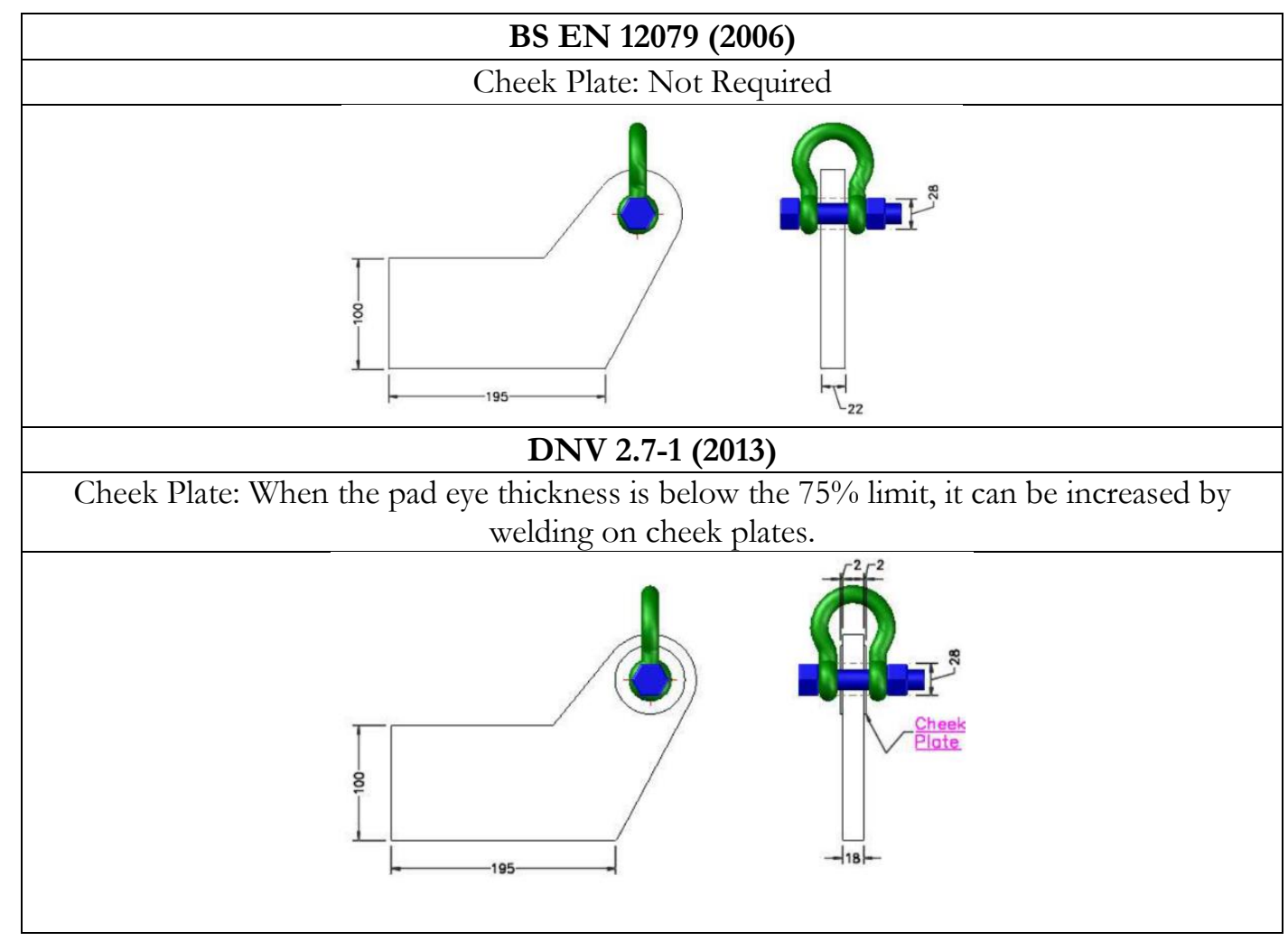

Kedua padeye diatas, ditempatkan kedalam slot dari CCU. Dengan ilustrasi di bawah ini: 


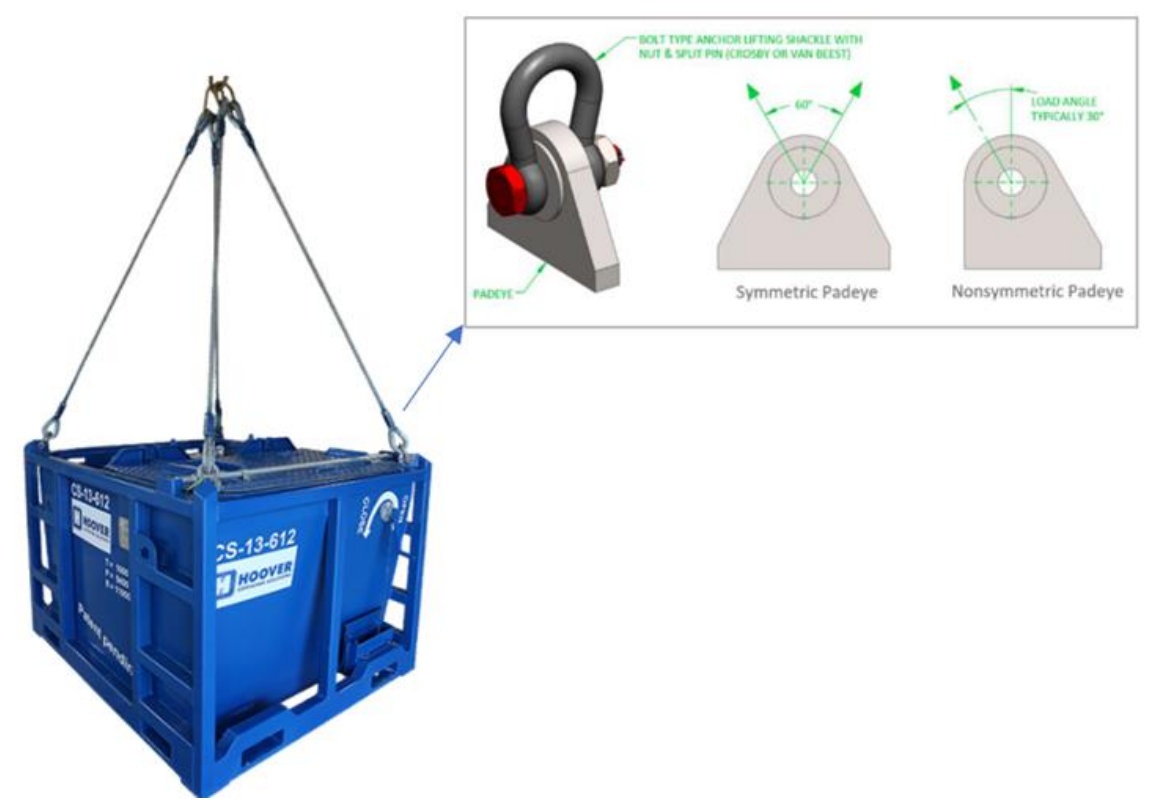

Gambar 1. CCU dengan lifting dan padeye (Ferguson, 2019)

Material padeye yang akan digunakan dalam penelitian ini adalah Material Baja ASTM A36. Material ini selain mudah didapat juga memiliki tingkat kekuatan dan keuletan yang baik.

Tabel 2. Komposisi kimia dan sifat mekanis material ASTM A-36

\begin{tabular}{|l|l|l|l|}
\hline \multicolumn{2}{|c|}{ Komposisi Kimia } & \multicolumn{2}{c|}{ Sifat Mekanis } \\
\hline Karbon, C & $0,25-0,29 \%$ & Masa jenis & $7.800 \mathrm{~kg} / \mathrm{m} 3$ \\
\hline Tembaga, Cu & $0,20 \%$ & Modulus tarik & $200 \mathrm{GPa}$ \\
\hline Besi, Fe & $98 \%$ & Modulus elastisitas & $140 \mathrm{GPa}$ \\
\hline Mangan, Mn & $1,03 \%$ & Rasio Poisson & 0,26 \\
\hline Fosfor, P & $0,04 \%$ & Regangan tarik & $75 \mathrm{GPa}$ \\
\hline Silikon, Si & $0,28 \%$ & Tegangan tarik & $250 \mathrm{MPa}$ \\
\hline Sulfur, S & $0,05 \%$ & $\begin{array}{l}\text { Tegangan tarik } \\
\text { maksimum }\end{array}$ & $400 \mathrm{MPa}$ \\
\hline
\end{tabular}

Sebagai ilustrasi, padeye yang diletakan pada mesin tes dengan beban tension-compression sampai terjadi perubahan bentuk geometri padeye. Maka, regangan maksimum yang terjadi pada padeye tersebut telah mencapai regangan tertinggi (ultimate strain) seperti ditunjukkan pada Gambar 2 berikut. 


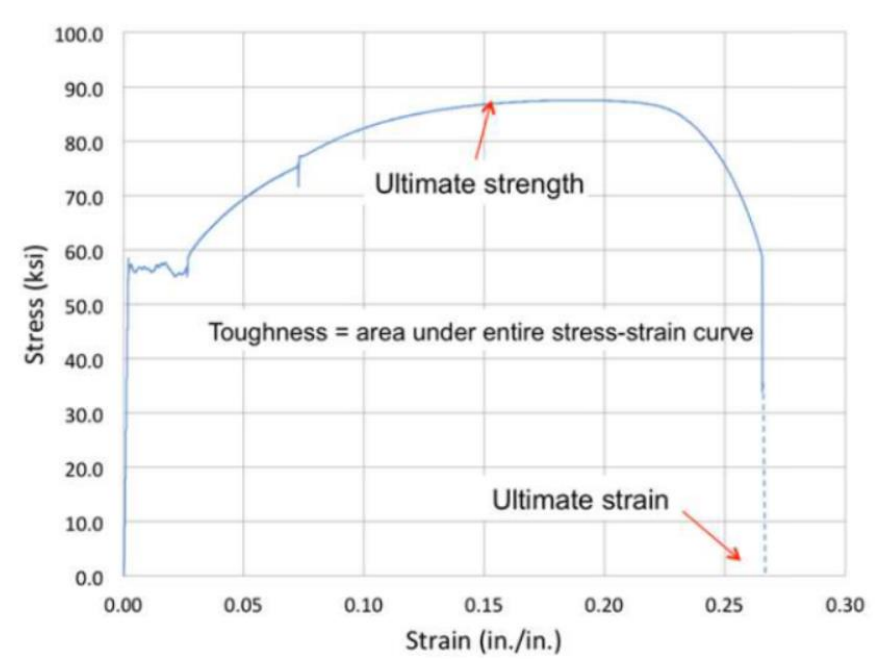

Gambar 2. Kurva Tegangan - Regangan

Dalam penentuan tegangan dan regangan yang terjadi, digunakan 2 metode yaitu dengan pendekatan engineering stress dan true stress. Pendekatan ini dapat digunakan untuk menjelaskan perilaku physical systems pada persamaan diferensial parsial, yang merupakan persamaan non-linear rumit yang menggambarkan sifat sistem tersebut. Salah satu alat yang paling umum digunakan untuk mencari solusi persamaan tersebut adalah Finite Element Method (FEM)

\subsection{Metode-metode pembebanan pada CCU}

Beban yang terjadi dapat dibedakan menjadi dua bagian yaitu beban pengangkatan (lifting loads) dan beban bentur (impacts loads).

1. Beban pengangkatan (Lifting Loads) berdasarkan DNV 2.7-1 \& BS EN 12079-1

Beban rencana pada struktur utama CCU dirumuskan:

$$
F_{L}=2,5 \times R \times g
$$

Nilai beban rencana ini dipengaruhi oleh beban gross (R) yang dipengaruhi juga beban gravitasi (g). Nilai g yang dipakai adalah $\sim 9,81 \mathrm{~m} / \mathrm{s}^{2}$

2. Gaya Resultan pada sling dapat dirumuskan:

$$
F=\frac{3 \cdot R_{g}}{(n-1) \cdot \cos v}
$$

Gaya resultan pada padeye beban gross $(\mathrm{Kg})$ yang diangkat dan dipertimbangkan juga dengan jumlah padeye (n) pada CCU tersebut. Faktor lain yang sangat mempengaruhi dari gaya resultan ini adalah sudut vertikal sling (v).

3. Beban Benturan (Impact Loads)

Beban benturan diasumsikan sebagai beban dinamik yang berdurasi singkat, dibagi menjadi dua yaitu benturan horizontal dan vertikal. Pada penelitian ini hanya dipertimbangkan benturan horizontal yang kemudian diasumsikan sebagai beban puntir. Nilai beban benturan didapatkan dari persamaan:

$$
F_{H I}=0,25 \times R \times g
$$




\subsection{Desain beban kapasitas pada padeye}

1. Pendekatan Teori

Mode kegagalan pada padeye yang menerima beban tarik ataupun puntir dapat terjadi secara terus menerus. Kegagalan itu terjadi di area yang berbeda pada struktur padeye yang digambarkan pada Gambar 3.

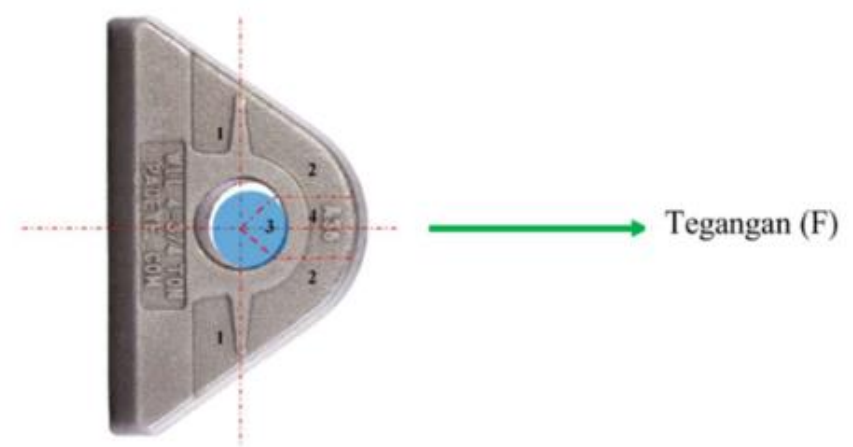

Gambar 3. Mode kegagalan pada padeye (Har-Bach, 2018)

Sebagaimana digambarkan pada skema di atas, mode kegagalan pada padeye terbagi menjadi empat (4) tipe kegagalan, (1) Kegagalan Tegangan/Tension Failure (2) Kegagalan Robek/Tear-Out Failure (3) Kegagalan Poros/Bearing Failure (4) Kegagalan Tegangan Melingkar/Hoop Tension Failure.

Pada penelitian ini, hanya akan diteliti kegagalan untuk kegagalan Robek (Tear-Out Failure) dan kegagalan poros (Bearing Failure). Dikarenakan kedua kegagalan tersebut sangat dasar dan umum digunakan sebagai desain kriteria untuk memperkirakan kapasitas beban pada padeye dan shackle.

2. Kegagalan Robek (Tear-out failure)

Desain kapasitas pada padeye untuk kegagalan robek dapat dirumuskan:

$P_{t}=2 . \tau_{R d} \cdot A_{s h}$

Dimana, tegangan geser didapatkan dari persamaan:

$\tau_{R d}=\frac{f_{y}}{y_{m, 1}} \sqrt{3}$

Tegangan geser ini dipengaruhi oleh tensile yield strength (Fy) dan safety factor yang didapatkan dari tabel dibawah ini.

Tabel 3. Partial Safety Factor

\begin{tabular}{|l|c|c|}
\hline \multicolumn{1}{|c|}{ Type of Calculation } & Material factor 1) & Value \\
\hline Resistance of Class 1,2 or 3 cross-sections & $\gamma_{\mathrm{M} 0}$ & 1,15 \\
\hline Resistance of Class 4 cross-sections & $\gamma_{\mathrm{M} 1}$ & 1,15 \\
\hline Resistance of member to buckling & $\gamma_{\mathrm{M} 1}$ & 1,15 \\
\hline Resistance of net section at bolt holes & $\gamma_{\mathrm{M} 2}$ & 1,3 \\
\hline Resistance of fillet and partial penetration welds & $\gamma_{\mathrm{MW}}$ & 1,3 \\
\hline Resistance of bolted connections & $\gamma_{\mathrm{Mb}}$ & 1,3 \\
\hline
\end{tabular}




$$
A_{s h}=\left(R-\frac{d_{h}}{2}\right) t_{p}
$$

Area tearing-out (Ash) ini ditentukan oleh Radius terluar (R), diameter lubang dari padeye (dh) dan ketebalan plate padeye (tp).

3. Kegagalan Poros (Bearing failure)

Dimana,

$$
P_{b}=f_{b, R d} \cdot t_{e f f} \cdot d
$$

$$
f_{b, R d}=1,5 \frac{f_{y}}{y_{m, 1}}
$$

Koefisien design shear strength ditentukan oleh parsial safety factor $\left(\mathrm{y}_{\mathrm{m}, 1}\right)$, ketebalan efektif dari padeye ( $\left.\mathrm{t}_{\mathrm{eff}}\right)$ dan diameter pin shackle (d)

\subsection{Penentuan beban padeye.}

Dengan asumsi beban hidup yang bekerja pada CCU sebesar 2 Ton, kemudian dilakukan kalkulasi menggunakan program struktur untuk mendapatkan gaya yang terjadi pada lifting point-nya. Selain beban hidup, juga diaplikasikan beban benturan horizontal untuk tinjauan beban puntir pada padeye.

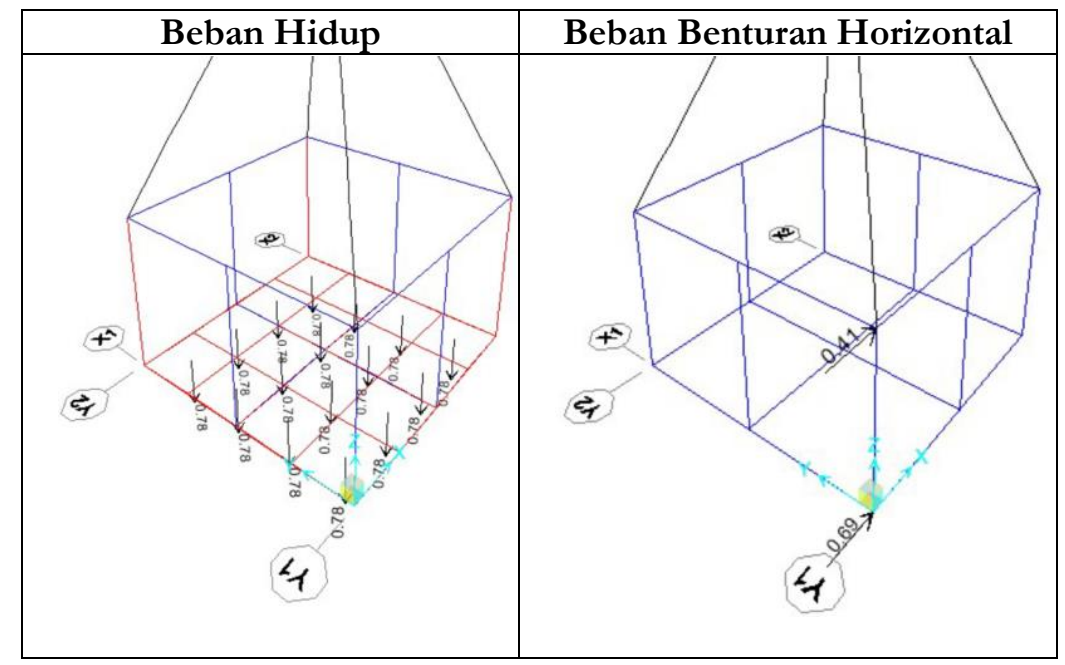

Gambar 4. Simulasi pembebanan pada CCU

Data output dari program kalkulasi tersebut dapat dilihat pada reaksi yang terjadi pada masing-masing lifting point-nya. 
F. Noviantoro dan I.Kusumaningtyas/ Journal of Mechanical Design and Testing 3(2), (2021), 103-117

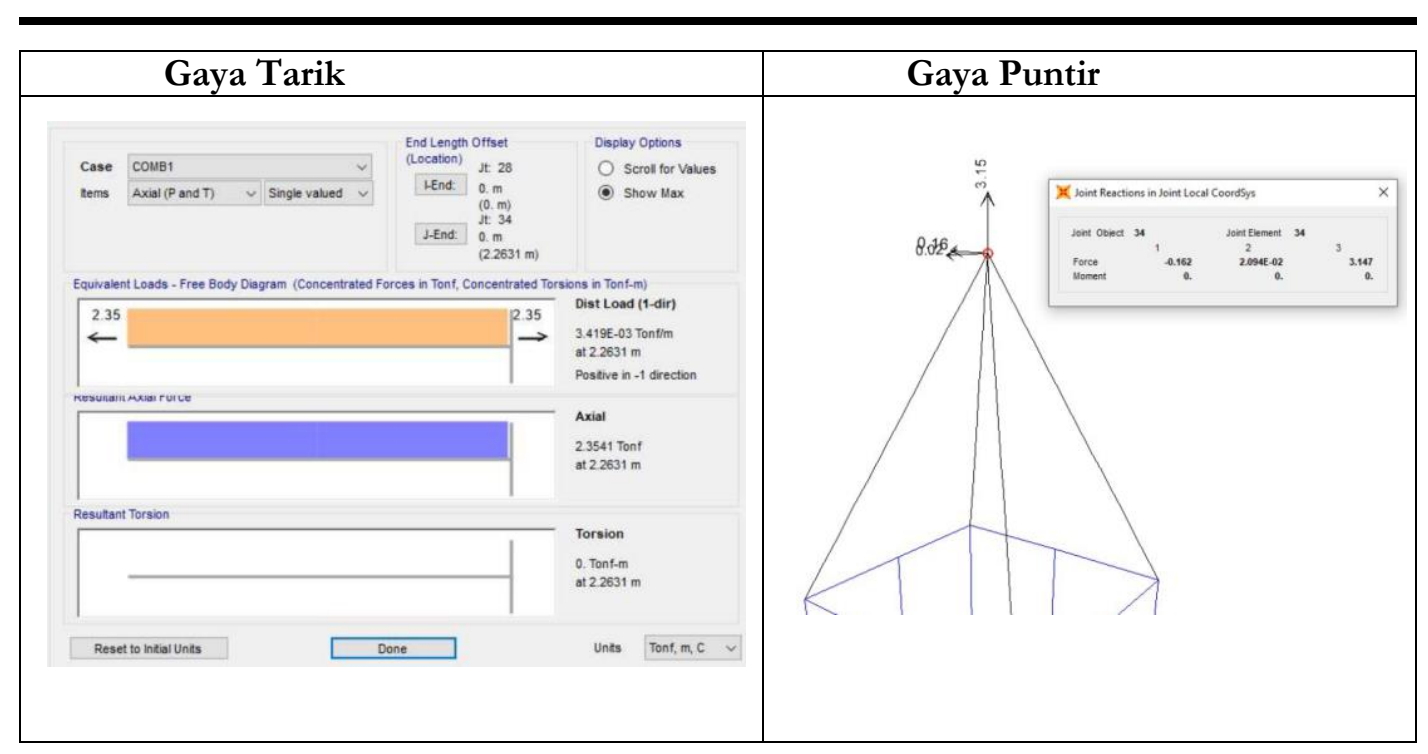

Gambar 5. Gaya yang terjadi pada CCU

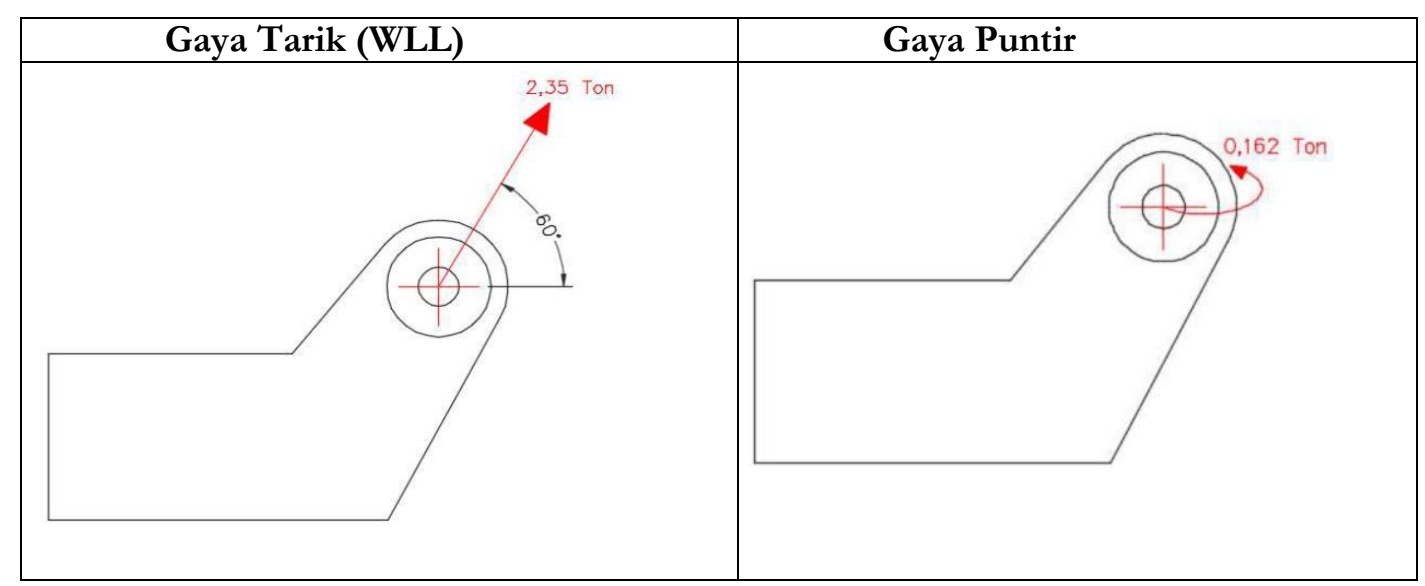

Gambar 6. Gaya yang terjadi pada padeye 
F. Noviantoro dan I.Kusumaningtyas/ Journal of Mechanical Design and Testing 3(2), (2021), 103-117

\subsection{Penentuan Dimensi}

Sebelum menentukan dimensi padeye, terlebih dahulu ditentukan kapasitas schakle-nya yang merujuk pada tabel berikut.

Tabel 4. Penentuan kapasitas shackle berdasarkan Kapasitas Angkat Aman (WLL)

\begin{tabular}{|c|c|c|c|c|c|c|c|c|c|c|c|c|c|c|c|}
\hline \multirow{2}{*}{$\begin{array}{l}\text { Nominal } \\
\text { Size } \\
\text { (in.) }\end{array}$} & \multirow{2}{*}{$\begin{array}{c}\text { Working } \\
\text { Load } \\
\text { Limit } \\
(\mathrm{t})^{*}\end{array}$} & \multicolumn{2}{|c|}{ Stock No. } & \multirow{2}{*}{$\begin{array}{l}\text { Weight } \\
\text { Each } \\
\text { (lbs.) }\end{array}$} & \multicolumn{9}{|c|}{ Dimensions (in.) } & \multicolumn{2}{|c|}{$\begin{array}{c}\text { Tolerance } \\
+/-\end{array}$} \\
\hline & & G-2130 & S-2130 & & A & B & C & $\mathrm{D}$ & $E$ & $\mathrm{~F}$ & $\mathrm{H}$ & $L$ & $\mathrm{~N}$ & $\mathrm{C}$ & A \\
\hline $3 / 16$ & $1 / 3 \ddagger$ & 1019464 & - & .06 & .38 & .25 & .88 & .19 & .60 & .56 & 1.47 & .98 & .19 & .06 & .06 \\
\hline $1 / 4$ & $1 / 2$ & 1019466 & - & .11 & .47 & .31 & 1.13 & .25 & .78 & .61 & 1.84 & \begin{tabular}{|l|}
1.28 \\
\end{tabular} & .25 & .06 & .06 \\
\hline $5 / 16$ & $3 / 4$ & 1019468 & - & .22 & .53 & .38 & 1.22 & .31 & .84 & .75 & 2.09 & 1.47 & .31 & .06 & .06 \\
\hline $3 / 8$ & 1 & 1019470 & - & .33 & .66 & .44 & 1.44 & .38 & 1.03 & .91 & 2.49 & 1.78 & .38 & .13 & .06 \\
\hline $7 / 16$ & $1-1 / 2$ & 1019471 & - & .49 & .75 & .50 & 1.69 & .44 & 1.16 & 1.06 & 2.91 & 2.03 & .44 & .13 & .06 \\
\hline $1 / 2$ & 2 & 1019472 & 1019481 & .79 & .81 & .64 & 1.88 & .50 & 1.31 & 1.19 & 3.28 & 2.31 & .50 & .13 & .06 \\
\hline $5 / 8$ & $3-1 / 4$ & 1019490 & 1019506 & 1.68 & 1.06 & .77 & 2.38 & .63 & 1.69 & 1.50 & 4.19 & 2.94 & .69 & .13 & .06 \\
\hline $3 / 4$ & $4-3 / 4$ & 1019515 & 1019524 & 2.72 & 1.25 & .89 & 2.81 & .75 & 2.00 & 1.81 & 4.97 & 3.50 & .81 & .25 & .06 \\
\hline $7 / 8$ & $6-1 / 2$ & 1019533 & 1019542 & 3.95 & 1.44 & 1.02 & 3.31 & .88 & 2.28 & 2.09 & 5.83 & 4.03 & .97 & .25 & .06 \\
\hline 1 & $8 \cdot 1 / 2$ & 1019551 & 1019560 & 5.66 & 1.69 & 1.15 & 3.75 & 1.00 & 2.69 & 2.38 & 6.56 & \begin{tabular}{|l|}
4.69 \\
\end{tabular} & 1.06 & .25 & .06 \\
\hline $1-1 / 8$ & $9 \cdot 1 / 2$ & 1019579 & 1019588 & 8.27 & 1.81 & 1.25 & 4.25 & 1.13 & 2.91 & 2.69 & 7.47 & 5.16 & 1.25 & .25 & .06 \\
\hline $1-1 / 4$ & 12 & 1019597 & 1019604 & 11.71 & 2.03 & 1.40 & 4.69 & 1.29 & 3.25 & 3.00 & 8.25 & 5.75 & 1.38 & .25 & .06 \\
\hline $1-3 / 8$ & $13-1 / 2$ & 1019613 & 1019622 & 15.83 & 2.25 & 1.53 & 5.25 & 1.42 & 3.63 & 3.31 & 9.16 & 6.38 & 1.50 & .25 & .13 \\
\hline $1-1 / 2$ & 17 & 1019631 & 1019640 & 20.80 & 2.38 & 1.66 & 5.75 & 1.53 & 3.88 & 3.63 & 10.00 & 6.88 & 1.62 & .25 & .13 \\
\hline $1-3 / 4$ & 25 & 1019659 & 1019668 & 33.91 & 2.88 & 2.04 & 7.00 & 1.84 & 5.00 & 4.19 & 12.34 & 8.80 & 2.25 & .25 & .13 \\
\hline 2 & 35 & 1019677 & 1019686 & 52.25 & 3.25 & 2.30 & \begin{tabular}{|l|}
7.75 \\
\end{tabular} & 2.08 & 5.75 & 4.81 & 13.68 & 10.15 & 2.40 & .25 & .13 \\
\hline $2-1 / 2$ & 55 & 1019695 & 1019702 & 98.25 & 4.13 & 2.80 & 10.50 & 2.71 & 7.25 & 5.69 & 17.90 & 12.75 & 3.13 & .25 & .25 \\
\hline 3 & +85 & 1019711 & - & 154.00 & 5.00 & 3.30 & 13.00 & 3.12 & 7.88 & 6.50 & 21.50 & 14.62 & 3.62 & .25 & .25 \\
\hline 3-1/2 & $+120 \ddagger$ & 1019739 & - & 265.00 & 5.25 & 3.76 & 14.63 & 3.62 & 9.00 & 8.00 & 24.88 & 17.02 & 4.38 & .25 & .25 \\
\hline 4 & $+150 \neq$ & 1019757 & - & 338.00 & 5.50 & 4.26 & 14.50 & 4.00 & 10.00 & 9.00 & 25.68 & 18.00 & 4.56 & .25 & .25 \\
\hline
\end{tabular}

Merujuk pada nilai WLL pada Gambar 6, maka nilai WLL yang digunakan untuk menentukan dimensi padeye adalah 3,25 Ton dan dapat digambarkan sebagai berikut:

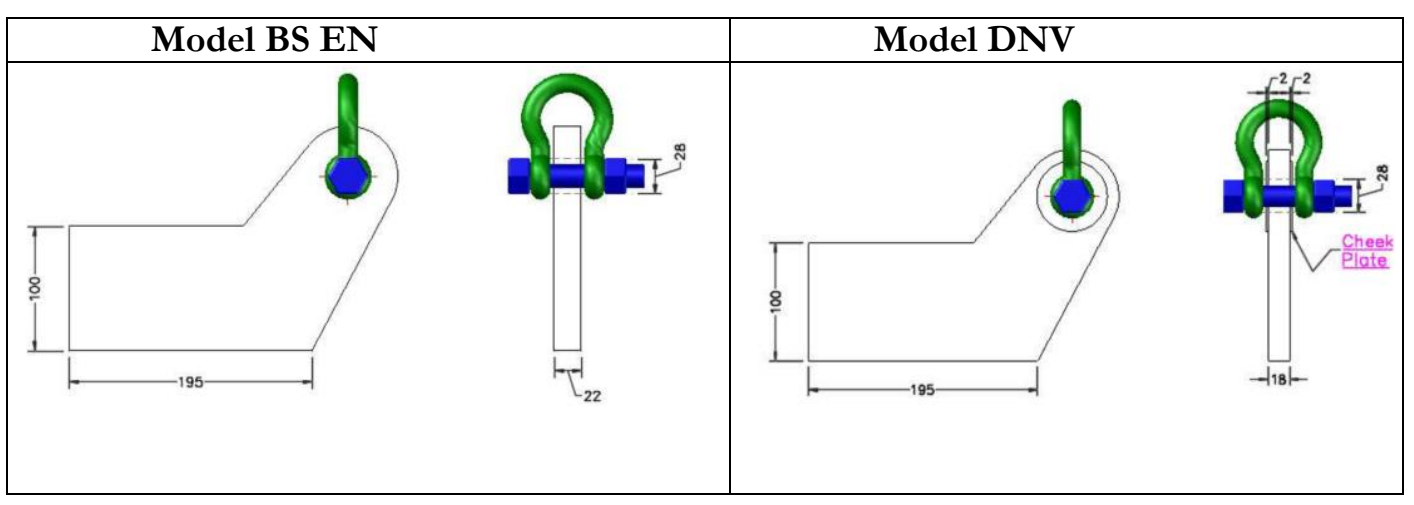

Gambar 7. Pemodelan dimensi padeye

\subsection{Analisa Tegangan dengan Finite Element}

Program yang digunakan untuk analisis tegangan adalah abaqus, berikut adalah langkah - langkah analisisnya:

1. Penentuan Satuan

2. Konfigurasi pemodelan

3. Pemilihan material (Material properties) 
4. Simulasi pembebanan (Load combination)

5. Penentuan titik tumpuan (Boundary Condition)

6. Penentuan Mesh pada model

7. Analisis hasil simulasi (Post processing for stress analysis)

\section{HASIL DAN PEMBAHASAN}

Untuk mendapatkan hasil analisis perbandingan yang detail dan akurat, padeye dianalisis kedalam beberapa area dan pola pembebanan diterapkan secara incremental.

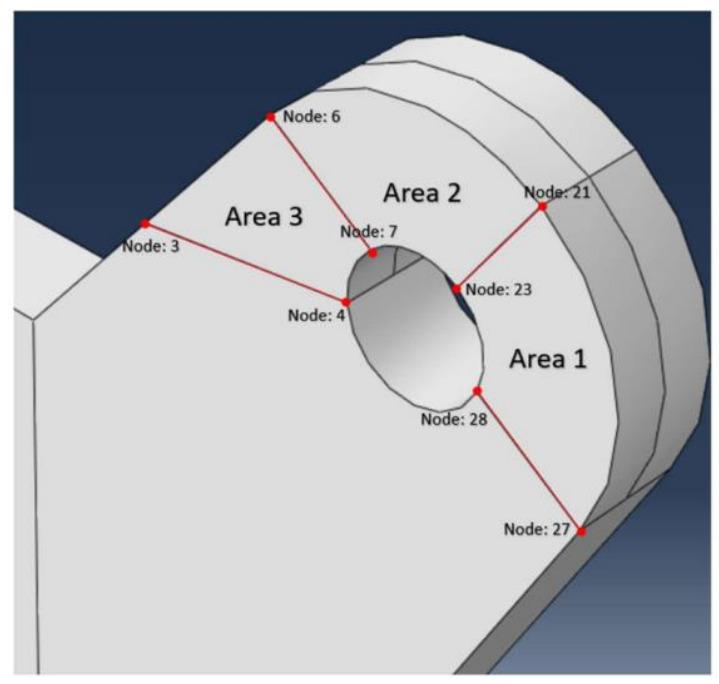

Gambar 8. Pembagian area untuk analisis

Tabel 5. Beban incremental tarik dan puntir

\begin{tabular}{|c|c|c|c|c|}
\hline \multirow{2}{*}{$\begin{array}{c}\text { Increment } \\
\text { Step }\end{array}$} & \multicolumn{2}{|c|}{$\begin{array}{c}\text { Tegangan Tarik } \\
(\text { Pressure) }\end{array}$} & \multicolumn{2}{c|}{$\begin{array}{c}\text { Tegangan Puntir } \\
(\text { Moment) }\end{array}$} \\
\cline { 2 - 5 } & Ton (T) & Pascal (Pa) & Ton (T) & $\begin{array}{c}\text { Pascal } \\
(\mathbf{P a})\end{array}$ \\
\hline 1 & 2.350 & $3.74 \mathrm{E}+07$ & 0.162 & $2.58 \mathrm{E}+06$ \\
\hline 2 & 3.525 & $5.61 \mathrm{E}+07$ & 0.243 & $3.87 \mathrm{E}+06$ \\
\hline 3 & 4.700 & $7.48 \mathrm{E}+07$ & 0.324 & $5.16 \mathrm{E}+06$ \\
\hline 4 & 5.875 & $9.35 \mathrm{E}+07$ & 0.405 & $6.45 \mathrm{E}+06$ \\
\hline 5 & 7.050 & $1.12 \mathrm{E}+08$ & 0.486 & $7.74 \mathrm{E}+06$ \\
\hline 6 & 8.225 & $1.31 \mathrm{E}+08$ & 0.567 & $9.03 \mathrm{E}+06$ \\
\hline 7 & 9.400 & $1.50 \mathrm{E}+08$ & 0.648 & $1.03 \mathrm{E}+07$ \\
\hline 8 & 10.575 & $1.68 \mathrm{E}+08$ & 0.729 & $1.16 \mathrm{E}+07$ \\
\hline 9 & 11.750 & $1.87 \mathrm{E}+08$ & 0.810 & $1.29 \mathrm{E}+07$ \\
\hline 10 & 12.925 & $2.06 \mathrm{E}+08$ & 0.891 & $1.42 \mathrm{E}+07$ \\
\hline 11 & 14.100 & $2.24 \mathrm{E}+08$ & 0.972 & $1.55 \mathrm{E}+07$ \\
\hline 12 & 15.275 & $2.43 \mathrm{E}+08$ & 1.053 & $1.68 \mathrm{E}+07$ \\
\hline
\end{tabular}


F. Noviantoro dan I.Kusumaningtyas/ Journal of Mechanical Design and Testing 3(2), (2021), 103-117

\subsection{Hasil Analisis dan Pembahasan}

Setelah dilakukan simulasi di Abaqus, diperoleh hasil perbedaan di antara masingmasing node yang ditinjau, yang menunjukkan beberapa karakteristik perbedaan penggunaan standar BS EN dan DNV. Tegangan yang dialami oleh padeye akan semakin meningkat seiring dengan peningkatan tekanan dan momen yang terjadi. Dalam penelitian ini, batasan tegangan padeye yang diizinkan adalah kurang dari 85\% dari SMYS (212,5 MPa).

Rangkuman diagram S_Mises vs Pressure + Moment yang terjadi pada padeye BS EN dan DNV.

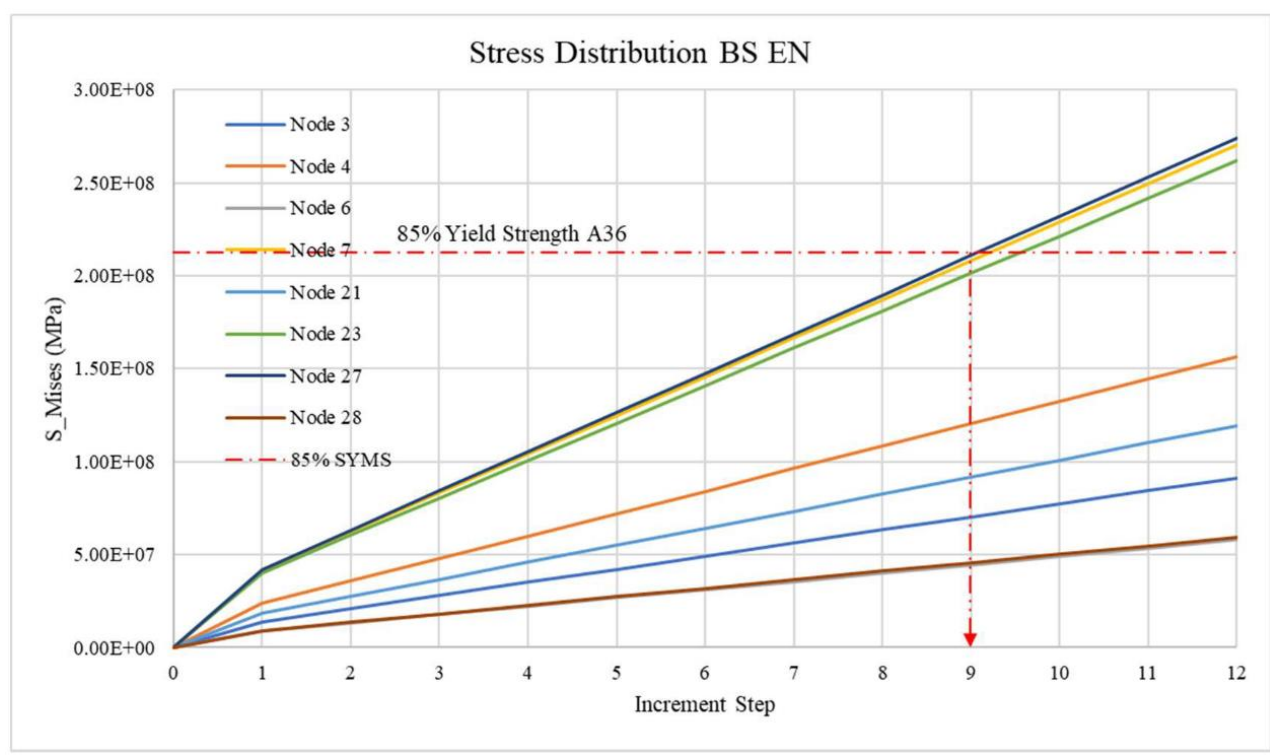

Gambar 9. Tegangan Von_Mises BS EN

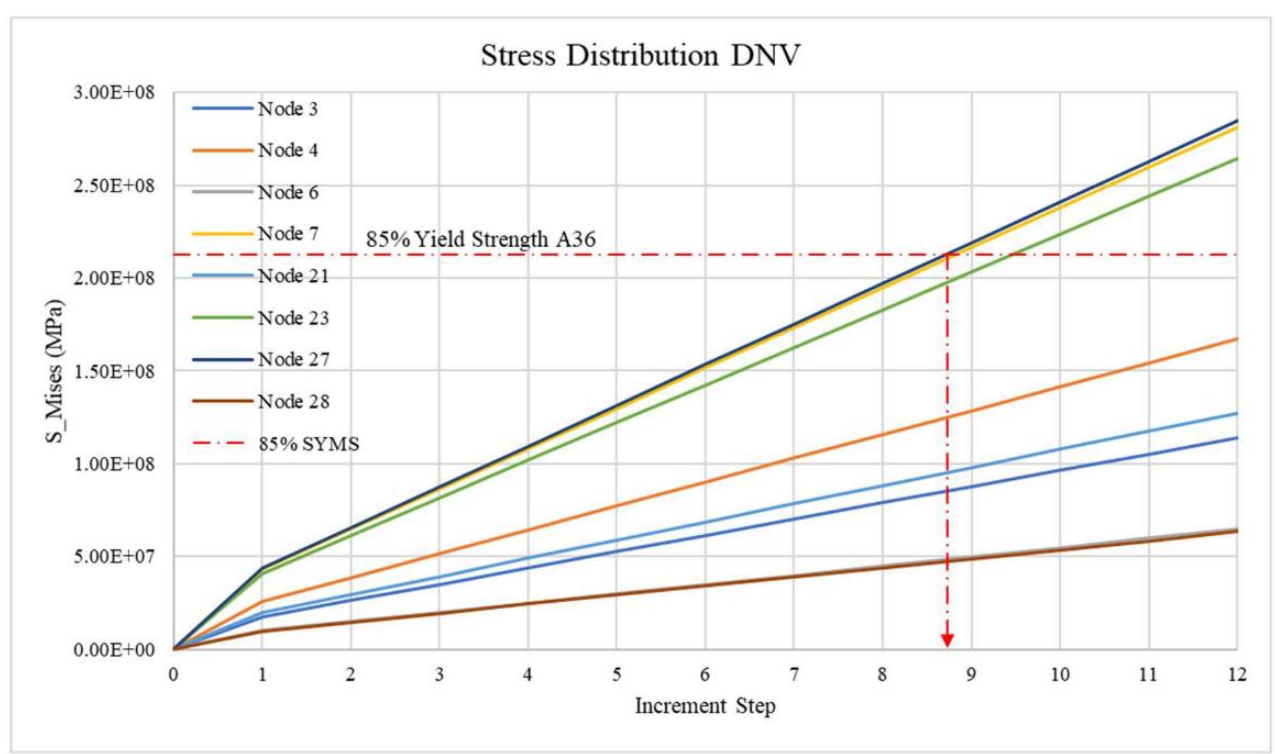

Gambar 10. Tegangan Von_Mises DNV 
Jika ditinjau dari batasan 85\% dari nilai yield strength material A36, dimensi padeye BS EN memiliki ketahanan lebih besar dari dimensi padeye DNV. Pada increment step ke-9 pemodelan padeye BS EN sudah menghasilkan tegangan maksimum yang berada pada nilai SMYS-nya, sedangkan pada pemodelan padeye DNV pada increment step yang kurang dari 9 sudah menyentuh tegangan maksimum SMYS-nya. Dalam bahasan selanjutnya, akan dijelaskan faktor dimensi dan pemodelan yang berperan pada besar kecilnya tegangan yang terjadi pada masing-masing Node baik untuk pemodelan secara BS EN dan pemodelan secara DNV.

\subsection{Control Tegangan dan Regangan Material Padeye}

Untuk mengetahui kapasitas padeye sampai pada kondisi patah dengan program Finite Element Analysis (FEA) dilakukan dengan metode nonlinear. Untuk itu diperlukan hubungan antara tegangan dan regangan dari material padeye mulai dari daerah elastis hingga daerah plastis. Karena kurva tegangan-regangan aktual dari tiap Node tidak diberikan pada literatur, maka digunakan pendekatan untuk menentukan regangan yang terjadi pada saat tegangan Von Mises menyentuh tegangan yield (yield strength).

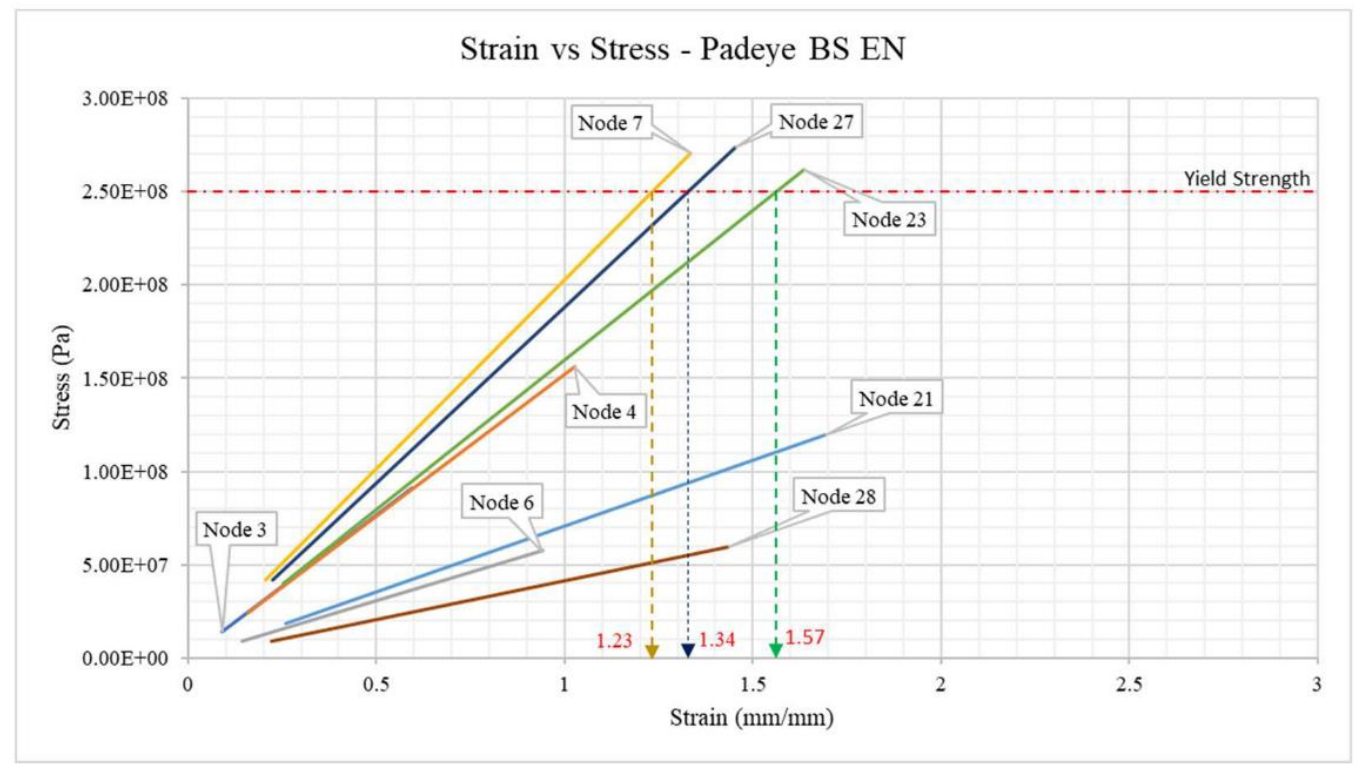

Gambar 11. Kurva tegangan - regangan padeye BS EN 


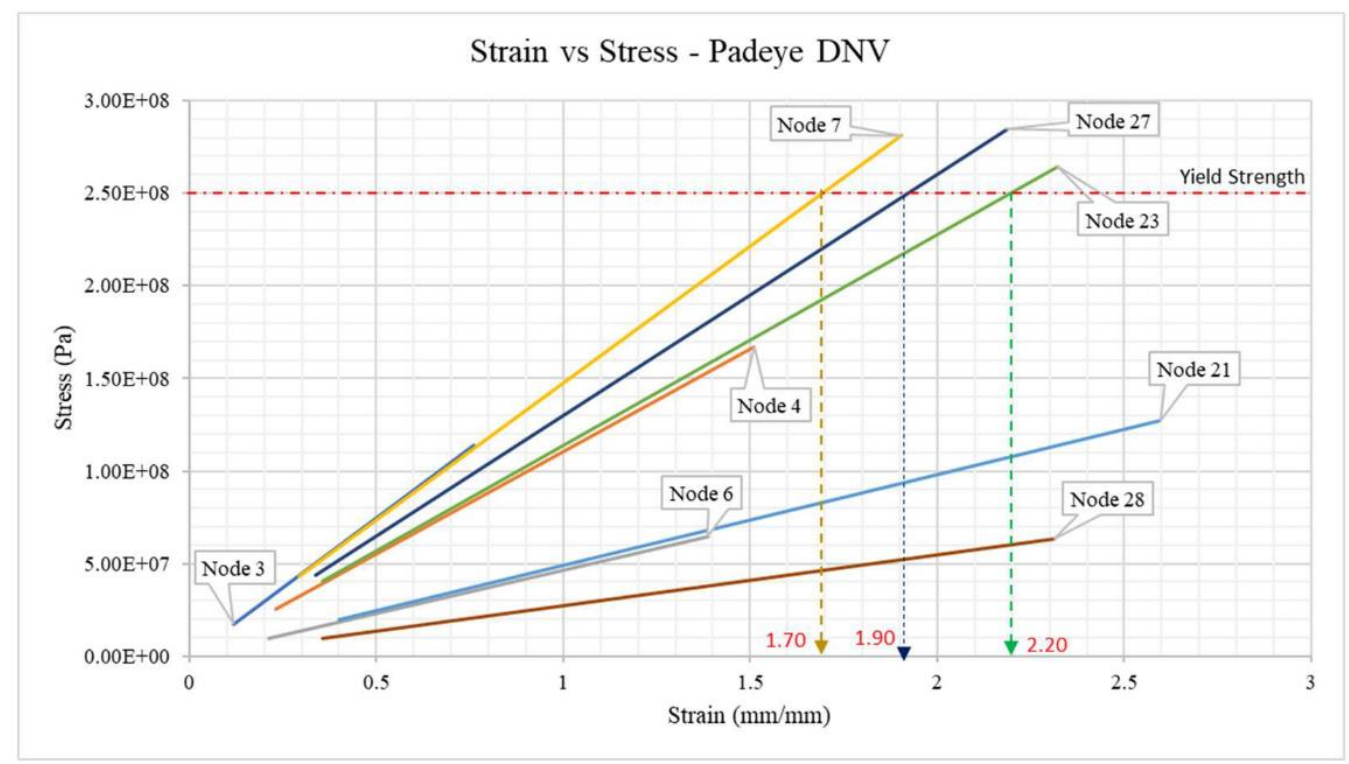

Gambar 12. Kurva tegangan - regangan padeye DNV

Nilai perbandingan regangan yang terjadi pada kurva Tegangan - Regangannya melebihi nilai tegangan ijin (250 MPa).

Tabel 6. Hasil Regangan dari Tegangan Yield

\begin{tabular}{|c|c|c|c|}
\hline \multirow{2}{*}{ Node } & \multicolumn{2}{|c|}{ Strain $(\mathrm{mm} / \mathrm{mm})$} & \multirow{2}{*}{$\begin{array}{c}\text { Persentase perbandingan nilai } \\
\text { Regangan antara BS EN dan DNV }\end{array}$} \\
\cline { 2 - 3 } & BS EN & DNV & $\frac{(1,70-1,23)}{1,23} \times 100 \%=38,21 \%$ \\
\hline 7 & 1,23 & 1,70 & $\frac{(2,20-1,57)}{1,57} \times 100 \%=40,13 \%$ \\
\hline 23 & 1,57 & 2,20 & $\frac{(1,90-1,34)}{1,34} \times 100 \%=41,79 \%$ \\
\hline 27 & 1,34 & 1,90 & \\
\hline
\end{tabular}

Jika diambil dari ketiga node di atas, selisih regangan yang terjadi pada padeye DNV mempunyai nilai regangan rata-rata 40\% lebih besar dibandingkan dengan nilai regangan yang terjadi pada padeye BS EN.

\subsection{Pembahasan}

Pemodelan yang telah dilakukan di Abaqus akan dibandingkan dengan hasil teoritical untuk ditinjau dari segi tegangan dan regangannya. Untuk mengidentifikasi kegagalan struktur dari padeye ini, nilai tegangan Von_Mises yang terjadi akan dibandingkan dengan nilai tegangan maksimum luluh (ultimate yield strength) dari material A36. Kriteria dari kegagalan tersebut didefinisikan sebagai berikut:

$$
\begin{gathered}
\sigma_{\text {von }} \leq \sigma_{u l t}=58 \mathrm{ksi}=400 \mathrm{MPa} \\
\varepsilon_{p} \leq \varepsilon_{u l t}=0,25 \mathrm{in} /{ }_{\text {in }}=6,6 \mathrm{~mm} / \mathrm{mm}
\end{gathered}
$$


Ditinjau dari nilai regangan yang terjadi dengan tinjauan beban normal, maka nominal regangan pada masing - masing node.

Tabel 7. Regangan pada increment 1 (Beban Normal)

\begin{tabular}{|c|c|c|}
\hline \multirow{2}{*}{ Node } & \multicolumn{2}{|c|}{ Regangan $(\mathrm{mm} / \mathrm{mm})$} \\
\cline { 2 - 3 } & BS EN & DNV \\
\hline Node 3 & 0,091 & 0,117 \\
\hline Node 4 & 0,158 & 0,232 \\
\hline Node 6 & 0,145 & 0,213 \\
\hline Node 7 & 0,205 & 0,293 \\
\hline Node 21 & 0,260 & 0,399 \\
\hline Node 23 & 0,252 & 0,357 \\
\hline Node 27 & 0,224 & 0,336 \\
\hline Node 28 & 0,221 & 0,356 \\
\hline
\end{tabular}

Regangan terbesar terjadi pada node 21 sebesar $0,399 \mathrm{~mm} / \mathrm{mm}$. Jika dibandingkan dengan nilai regangan maksimum (ultimate strain) untuk material A36 yaitu sebesar $6,6 \mathrm{~mm} / \mathrm{mm}$. Maka nilai regangan pada node 21 tersebut masih jauh dibawah nilai yang di izinkan untuk material A36.

\section{KESIMPULAN}

Dari hasil analisis padeye pada struktur CCU dapat diambil beberapa kesimpulan, antara lain:

1. Ditinjau dari tiga Node yang menyentuh tegangan yield $250 \mathrm{MPA}$, Nilai regangan yang terjadi pada padeye BS EN rata-rata 40\% lebih kecil daripada regangan yang terjadi pada padeye DNV.

2. Dari tinjauan 8 Node yang ditentukan, pemodelan padeye BS EN mendapatkan nilai displacement yang terjadi dengan rata-rata $46 \%$ lebih kecil daripada pemodelan padeye DNV. Didapatkan juga perbedaan signifikan displacement terjadi pada Node 28, dimana displacement yang terjadi pada padeye DNV 61\% lebih besar dari nilai displacement padeye BS EN. Hal ini dikarenakan struktur utama padeye memiliki selisih ketebalan yang signifikan antara padeye BS EN dan DNV. Dan Cheek Plate yang diaplikasikan pada pemodelan padeye DNV tidak berpengaruh signifikan pada perkuatan struktur utamanya.

3. Tegangan Von_Mises yang terjadi pada Padeye DNV telah mencapai nilai batasan tegangan yield material A36 (212,5 MPa) pada increment ke-9 pada tinjauan Node 27. Sedangkan untuk pemodelan padeye BS EN pada increment ke-9 tersebut belum mencapai nilai batasan yield strength material A36 $(212,5 \mathrm{MPa})$.

4. Ditinjau dari nilai batasan tegangan yield dari material A36 (212,5 MPa), Untuk pemodelan padeye BS EN pada increment ke 11 telah melebihi batas tegangan yield tersebut dengan persentase $104,22 \%$ pada node 23 . 


\section{DAFTAR PUSTAKA}

ABAQUS, 2008, Manual Book Version 6.8: Getting started with Abaqus, Tutorial Edition, Abaqus, Inc.

ASTM, 2015, ASTM A36/A36M14: Standard Specification for Carbon Structural Steel, Material properties, American Society for Testing and Materials

BS EN, 2006, BS EN 12079-1: Offshore containers and associated lifting sets — Part 1: Offshore containers, Recommended Practice, British Standard European Norm

BS EN, 2006, BS EN 12079-2: Offshore containers and associated lifting sets — Part 2: Lifting sets, Recommended Practice, British Standard European Norm

BY Y. Higashida, J. D. Burk, AND F. V. Lawrence, JR., 1978, Strain Controlled Fatigue Behavior of ASTM A36 and A514 Grade F Steels and 5083-0 Aluminum Weld Materials, Welding research supplement, pp 334-344

Chevron, 2009, MCA, Lifting and Rigging Standard. Houston: Chevron Corporation.

Crosby Catalogue, 2003, Crosby Bolt-Type Shackles

Daniela Scorza, Andrea Carpinteri, Sabrina Vantadori, 2018, Tension failure assessment at lug hole edges, International Journal of Fatigue, Department of Engineering \& Architecture, University of Parma.

DNV, 2013, DNV Recommended Practice 2.7-1: Standard for Certification of Offshore Containers, Recommended Practice, Det Norske Veritas

Gérald Portemont, Julien Berthe, Alain Deudon, François-Xavier Irisarri, 2018, Static and dynamic bearing failure of carbon/epoxy composite joints. DMAS, ONERA, University Paris Saclay. Composite Structures, Université Paris Saclay, France

Hikmat Saaid Saleh, 2016, Ultimate capacity of pad eyes in lifting operations, $A$ thesis submitted to the Faculty of Science and Technology, University of Stavanger, Norway

Iqbal Gayuh R.M.S, Yeyes M, dan Yoyok S.M., 2016, Analisis Keandalan Struktur Padeye Berdasarkan Konfigurasi Rigging pada Lifting Upper Deck Modul MODEC dengan Pendekatan Dinamik. Jurusan Teknik Kelautan, Technical Journal, Fakultas Teknologi Kelautan, Institut Teknologi Sepuluh Nopember (ITS), Indonesia.

Roberto Leon, 2018, Journal of Visualized Experiments, Stress-Strain Characteristics of Steels. Department of Civil and Environmental Engineering, Technical Journal, Virginia Tech, Blacksburg, VA

T.W. Ling, X.L. Zhao, R. Al-Mahaidi, J.A. Packer, 2006, Investigation of block shear tearout failure in gusset-plate welded connections in structural steel hollow sections and very high strength tubes. Technical Journal, Civil Engineering, Faculty of Civil Engineering, Monash University. 